\title{
Improving Students' Entrepreneurial Interest using Production Based Learning Model in TVET
}

\author{
Indrati Kusumaningrum $^{\mathrm{a}, 1}$, Ganefri $^{\mathrm{a}}$, Hendra Hidayat $^{\mathrm{a}}$ \\ Postgraduate Engineering Faculty, Padang State of University \\ Padang, INDONESIA \\ ${ }^{1}$ inkoes_pdg@yahoo.co.id
}

\begin{abstract}
This research is aimed to describe the improving of students' entrepreneurial interest by using Production based Learning Model in Technical Vocational Education and Training (TVET) in Higher Education. This research is a descriptive research with qualitative approach, used standard instrument to measure index of students' entrepreneurial interest, and had 33 students as the research subject. Based on the result of the research, most of the students have had entrepreneurial interest. It can be seen from preliminary data of nine indicators of students' entrepreneurial interest. There is only two students who meet the indicators of success criteria above sixty percent. Then, the researcher implemented Production based Learning Model. It improves only three indicators which had not ever fulfilled the indicators of success. Therefore, it is important to conduct second implementation in order to be able to identify more students' entrepreneurial interest. For the second implementation, all the indicators of entrepreneurial interest have been fulfilled. In its implementation, Production based Learning Model can increase experiences and improve understandings as in competencies (cognitive, affective, and psychomotor), and also students' entrepreneurial skill which have impact towards the improving of students' entrepreneurial interest. Production based Learning Model provides spaces for the students to be more adventurous, creative, and critical thinking towards what they do. Besides that, it can give plus value scientifically and financially to be accepted by societies as a goods and services needed. It is time for the Stakeholder of TVET in Higher Education to try to implement the Production based Learning Model in learning process.
\end{abstract}

Index Terms - production based learning model, entrepreneurial interest

\section{Introduction}

Vocational education is middle education which prepares the students especially for working in certain field (UU No. 20 Tahun 2003 pasal 15). Vocational education has mission to prepare the students to be able to face changes in their community especially for working in certain field. Therefore, Technical Vocational Education and training (TVET) has contribution towards country development to be better. It is supported by [25] who said that "....TVET is concerned with the acquisition of knowledge and skills for the world of work to increase opportunities for productive work, sustainable livelihoods, personal empowerment and socio-economic development in knowledge economies, to increase their chances for employability, young people and adults need skills that are adaptable and relevant to the demands of today's societies, which require individuals to possess a combination of knowledge, practical and social skills and positive attitudes and the ability to adapt to rapidly changing work environments.....". From this explanation it can be seen that TVET try to develop an individual ability to be able to survive in social life with skill which they have and give impact of changes and economic social development. Besides, vocational education is expected to create skilled worker in the effort of improving productivity and efficiency including readiness towards International worker market competition in globalization era.

In principle, TVET in a country play the important role and most strategic. In contrast, TVET in Indonesia have not been noticed and developed totally. National problem complexity which is growing especially related to educated unemployment, based on Central Bureau of Statistics (BPS) data which is launched per February 2014, number of open unemployed recorded is $5.7 \%$ or 7.15 Million people. This number is decrease compared to February 2013 which is $5.83 \%$ (7.2 million people) as well as August 2013 which is $6.17 \%$ (7.41 Million people). Then, Central Bureau of Statistics (BPS) recorded the absorption of employee is still dominated by people which are elementary school graduates, 52 million people or $46.95 \%$ of total of Indonesian employees. Elementary School graduated. For employees who are junior high school graduated reach 20.5 million people or 18.47 percent. People who are high education graduated only 10.5 million people where 2.9 million people are Diploma graduates and 7.6 million people are university graduates. This is no exception in the learning process which is implemented in Faculty of Engineering of The State University of Padang which still results output from each skill but has never touch outcome; they are the balancing between cognitive, affective, and psychomotor ability including having entrepreneurship skill. In fact, university graduates are still as job seeker not as a job creator.

This effort is important to be implemented to overcome the increasing the number of educated unemployed by preparing university graduates which have entrepreneurships interest. Entrepreneur is an alternative solution overcoming unemployed and poverty by creating jobs or entrepreneurship.

This term is in accordance with Instruksi Presiden Nomor 4 Tahun 1995 regarding to National Movement of promoting and cultivating Entrepreneurship. This instruction mandates to all people and Indonesia to develop entrepreneurships program. Then, in supporting Creative Economic Development (PEK) year 2010-2014; the development of economics activities based on individual creativities, skills, and interests to create individual creativity which economic valued and have effect towards welfare of Indonesian People.

The real alternative solution that can be implemented through innovation in the learning process which is relevant to the needs of Technical Vocational Education and training 
(TVET) in higher education, one of the learning model implementation used is Production based Learning Model which can give impact towards the improvement of students' entrepreneurships interest, based on the preliminary data which is collected from test that is given to 33 students. The data as follow:

Table 1. Preliminary data regarding students' entrepreneurships interest in Faculty of Engineering of The State University of Padang.

\begin{tabular}{clc}
\hline No & $\begin{array}{l}\text { Indicators of Students' } \\
\text { Entrepreneurships Interest }\end{array}$ & Average \\
\hline 1 & Entrepreneur Attitude & 60.48 \\
2 & Locus Internal control & 65.23 \\
3 & Motivation Ability & 40.34 \\
4 & Self-Confident & 30.87 \\
5 & Needs of Achievement & 60.12 \\
6 & Simply Risk Taking & 47.96 \\
7 & Entrepreneurship Moral Value & 48.57 \\
8 & Entrepreneurship Thinking & 46.83 \\
9 & Entrepreneur behavior & 55.19 \\
\hline Source : Data preliminary tests using PIKEN
\end{tabular}

From this data, it can be seen the average of indicators of students' entrepreneurships interest is still low. Indicators of students' interest is success if the average of indicators of students' interest above $60 \%$. From the table 1, there are only two indicators which fulfill succeed indicators. It proves that students' entrepreneurships interest is still low. Consequently, there are some factors that can affect the low of students' entrepreneurships interest. One of them is learning process which implements the learning model that less facilitates students' entrepreneurships interest. Hence, in the practice of creating a product or a tool, the students are only mark oriented as their obligation and task of creating the product. It has not trained to create product for social and market needs.

Based on the introduction above, the aim of this research is to describe the improvement of students' entrepreneurships interest by using Production based Learning Model in the Technical Vocational Education and training (TVET) of Higher Education.

\section{Literature Review}

\section{A. Review about Entrepreneurship in Technical Vocational Education and Training (TVET) in Higher Education}

Entrepreneurship basically is an activity process which is done by two or more people with the certain aim and motivation. Entrepreneurship is a real effort in reaching the success, which of course should be accompanied with hard work and high spirit. Someone who has behavior and spirit of entrepreneur is someone who always wants to be success and try hardly in all fields that they joined [40], [5], [1], [31]. TVET has important role in the way of directing, facilitating and developing the entrepreneurships for the students that entrepreneurships also have orientation to build qualified people from pre entrepreneur into becoming a entrepreneur [22]. [30] argues that entrepreneur education stick to learning of dimension of behavior and thinking beside entrepreneur skill. Specifically, one of the characteristics of someone has entrepreneur soul which can be seen from their entrepreneur interest.

\section{Entrepreneurship Interest}

Entrepreneurial interest in a someone basically, is a motivation to start doing entrepreneur activities, in the form of services or goods. However, this entrepreneurial interest is also identical with doing something different and interested innovation and breakthrough in the organization or firm. The someone entrepreneurships interest specially students is affected by some factors, [38]. Moreover, [34] students' entrepreneurial interest is determined by their entrepreneurship competencies. It is supported by [37] explains that students' entrepreneurial interest arise when they start their business. According to [35], build a school with the real work based learning and fit to the market condition, so that it will affect students' interest in the entrepreneurships. [11], make a curriculum which facilitates the students in the entrepreneurships education experiences, which later it will give understandings to the students and their entrepreneurships interest, will arise. From the definition of the interest above, it can be concluded that students' entrepreneurial interest especially in the vocational education can be arise if it is affected and formed by a learning which will affect the arising of the interest

\section{B. Review About Production Based Learning Model with Entrepreneurship}

Model is a systematic pattern or reference which can be a guideline for Educators. Learning model is a direction from learning implementation which is implemented by the Educators with the aim to guide the active students in learning process. [28] the term of learning model of regular work procedure and systematic and has thinking, remarks, or explanation from the concept. [33] means that learning as interaction process between Educators and students who support them to learn actively, participatively, and interactively by using methods, approaches, and media, and appropriate learning environment. [32] defines that learning as a basic in adding information of having new knowledge process. Therefore, it can be stated that learning model is a procedure or steps which are needed by educators to facilitate their students to learn actively, participatively, interactively with the aim to reach education goals; the development of the students' potential optimally.

Learning model in the Technical Vocational Education and Training (TVET) in Higher Education is expected to be able to give impact towards the students' outcomes especially in the entrepreneurships skill. Implication in the process of entrepreneurship education in the TVET in the higher education should involve active learning process such as discovering learning method, problem solving, experiment, simulation; project and speech [39], [16]. In the higher education, entrepreneur education will involve searching and discovering thinking process of something new. In accordance with “.....the process of inquiry and the application of critical thinking provide the necessary conditions for learning and knowing [3], [4], [6], [7], [9], [17], [18]....". Then, [2] in Australia shows that there is a need for entrepreneurship education in the university. 80 percent respondent of academics have positive attitude towards entrepreneurship education.

The importance of entrepreneurship in the TVET in the higher education, as stated by [27] that the promotion of entrepreneurship education at various levels of the tertiary education so that more and more graduates of the system 
can set up their own business, create employment and alleviate poverty in the society. [19] observes that each year, generally new small business (including those related to technology) are started in the country but only half are in existence for up to eighteen months or less while only very few last after twenty four months. They thus attributed this situation to lack of skills occasioned by lack of requisite training in entrepreneurship.

Entrepreneurship education in the TVET in the higher education is not a new thing. It has been existed before, but it has not been focused to the implementation of the entrepreneurships. The focus has been much more on preparing for management in (big) companies. The same can be observed in other countries [21], [20], [26], [23] Initiatives to connect knowledge production and entrepreneurship are blossoming, as shown by the recent appointment of professors of 'knowledge and entrepreneurship' in several universities [10], [8]. One interesting example found in higher vocational education was the new content and didactic arrangements in the course for Small Business and Retail Management at the higher vocational Saxion College in Enschede [24]. Learning objectives are derived from an entrepreneurial competencies profile, inspired by [15]. One of the TVET curriculum implementation in the curriculum as stated by [13], production based learning with entrepreneurship approach using workshop based lectures, qualitatively improved the quality and meaningfulness of the learning....., the learning activity gives impacts to the cognitive discourse, psychomotor skill, and work attitude improvement build integrally, Thus the model is deemed suitable to be utilized in the learning to improve the students' entrepreneurial interest.

One of the learning model which is fit to the needs of entrepreneurship education is Production Based learning Model, with the steps as follow; (1) Analysis of curriculum and learners characteristics; (2) Identification and product analysis; (3) Creating important questions about product; (4) Questions mapping; (5) analysis of equipment and materials needed of the product which was going to be made; (6) making schedule of implementation of making product; (7) process of making product; (8) evaluated regularly; and (9) creating business plan [12].

\section{Research Methods}

This research used descriptive research, descriptive research is a kind of research which the most fundamental research. It is aimed to describe phenomena of nature of engineered. This research reviews forms, activities, changes, relations, similarities, and differences with other phenomena [36]. The data analysis used statistics descriptive. In the implementation of this research, the researcher used PIKEN where it can be used to measure index of someone' entrepreneurships interest. According to [14], it was developed by CESMED Fellow, Also Prof Dr Nor Aishah Buang from the Faculty of Education to gauge a student's business acumen based on his psychometric index by measuring his aptitude, level of thinking and department.

\section{Results and Discussion}

The result of this research refers to syntax of production based learning model, they are; (1) Analysis of curriculum and learners characteristics; (2) Identification and product analysis; (3) Creating important questions about product; (4) Questions mapping; (5) analysis of equipment and materials needed of the product which was going to be made; (6) making schedule of implementation of making product; (7) process of making product; (8) evaluated regularly; and (9) creating business plan [12]. Then, in the step of implementation of the production based learning model by using entrepreneurship psychometrics, this instrument was used to the impact of the use of production base learning model towards the students' entrepreneurships interest. In this measurement, there are nine indicators that can be identified, as follow:

1. Entrepreneur Attitude

2. Locus Internal control

3. Motivation Ability

4. Self-Confident

5. Needs of Achievement

6. Simply Risk Taking

7. Entrepreneurship Moral Value

8. Entrepreneurship Thinking

9. Entrepreneur behavior

From the test that was done to the 33 students of Electrical Engineering by using standard PIKEN instrument in measure students' entrepreneurships, it can be get the average as follow:

Table 2. Average of students' entrepreneurships interest Indicators Phase I

\begin{tabular}{cll}
\hline No & $\begin{array}{l}\text { Indicators of Students' } \\
\text { Entrepreneurships Interest }\end{array}$ & $\begin{array}{c}\text { Average } \\
\text { Percentage }\end{array}$ \\
\hline 1 & Entrepreneur Attitude & $66.48 \%$ \\
2 & Locus Internal control & $72.92 \%$ \\
3 & Motivation Ability & $58.36 \%$ \\
4 & Self-Confident & $56.27 \%$ \\
5 & Needs of Achievement & $69.27 \%$ \\
6 & Simply Risk Taking & $57.96 \%$ \\
7 & Entrepreneurship Moral Value & $68.57 \%$ \\
8 & Entrepreneurship Thinking & $66.33 \%$ \\
9 & Entrepreneur behavior & $65.39 \%$ \\
\hline
\end{tabular}

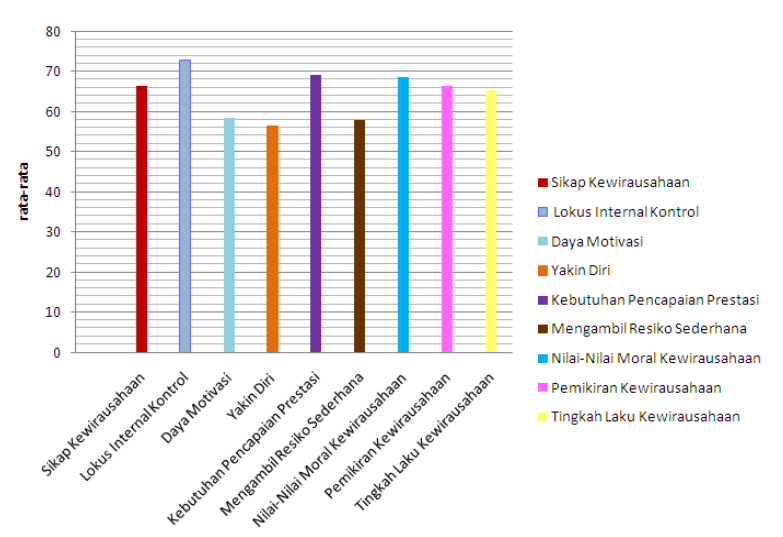

Graph 1. Average of students' enterpreneurships interest Indicators Phase I

From the table 1. Regarding Average of students' entrepreneurships interest Indicators Phase I, it can be seen that students' entrepreneurial interest is still below $60 \%$. Therefore, it needed to conduct second Phase. 
Table 2. Average of students' entrepreneurships interest Indicators Phase II

\begin{tabular}{clc} 
No & \multicolumn{1}{c}{$\begin{array}{c}\text { Indicators of Students' } \\
\text { Entrepreneurships Interest }\end{array}$} & $\begin{array}{c}\text { Average } \\
\text { Percentage }\end{array}$ \\
\hline 1 & Entrepreneur Attitude & $71.48 \%$ \\
2 & Locus Internal control & $78.20 \%$ \\
3 & Motivation Ability & $70.76 \%$ \\
4 & Self-Confident & $67.47 \%$ \\
5 & Needs of Achievement & $79.87 \%$ \\
6 & Simply Risk Taking & $69.93 \%$ \\
7 & Entrepreneurship Moral Value & $77.55 \%$ \\
8 & Entrepreneurship Thinking & $76.33 \%$ \\
9 & Entrepreneur behavior & $73.89 \%$ \\
\hline
\end{tabular}

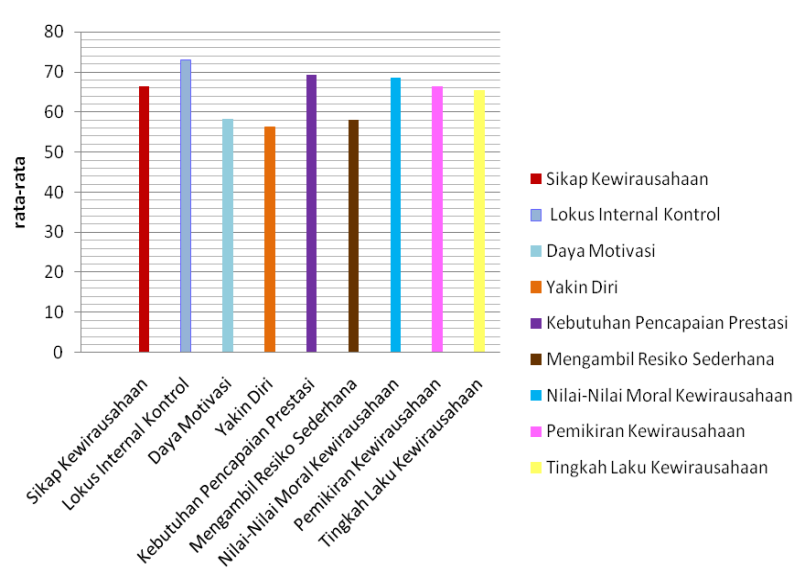

Graph 2. Average of students' enterpreneurships interest Indicators Phase II

Based on the result of the research above, as in the graphic 1, the psychometric indicators of entrepreneurships of students' average shows the students have had entrepreneurships interest from the average of 33 students. However, it is important to be noticed that self-confident aspect shows $56.27 \%$ which means that the degree of the students' self-confident is still low, and of course there are many factors that affect it. Based on the result of observation, almost all of the students self-confident in university are low. This condition is as well as [29]. He states that entrepreneur tend to confident on their capability to be success and they tend to be optimistic on their success opportunities. The students' self-confident is also affected towards opportunity and income that they get. However, in the part of Internal Locus Control, the average shows statistical result, $72.9 \%$, where Internal Locus Control is related to the individual expectation which is beyond their self control. The Phase II shows the improvement of aspect of self confident, $67.47 \%$. It means that the degree of self confident of the students has been increased. It is caused by the learning process using production based learning model. The students are given more opportunities to be active in the asking questions, discussion, and responding by delivering important statements that are related to product that are going to be made. Other improvement is also seen in some other indicators of students' entrepreneurial interest. It is caused by learning condition which is facilitated to create learning as in world of work by considering product quality towards society needs and product selling price.

\section{Perspective of Production Based learning Model towards Outcomes resulted and market Demand}

Vocational education generally is still limited to reach output target. The graduates are still not touch outcomes, even long term in impact form. This condition is influenced by readiness of educators and also facilitation and infrastructure learning supports.

Besides, coordination and evaluation and analysis of market needs from entrepreneur world demand and industry even human source needs in creating new work field through vocational education, especially in higher education. It leads to find learning alternatives that can facilitate market needs.

This production based learning model is one of the alternatives that is offered to Technical Vocational Education and training (TVET) in higher education. It is relevant with the needs and TVET expectation in this free trading needs. By using this production based learning model, the students are trained to think critically, creatively, and confident to deliver their idea and exploring to be a product that will be made in a product plan. Thus, it is orientation is to the society needs without put aside existed competitor.

After the product has been resulted, the next step is creating business plan from the product that has been created. In creating business plan indirectly the students have done the analysis and evaluation towards specific competitor, especially related to product quality, selling price and to what extent the consumer need the product that are made.

This process will go back again to the initial idea and reconstruct and revision of ideas, and re-explore sources and other technical aspect, so that indirectly will add experience and improve the understandings in competencies (cognitive, affective, and psychomotor) including students' entrepreneurships interest, which will affect the improvement of students' entrepreneurships interest. This condition will be more better if the stakeholder, where all students' creation and product even in the form of goods or services can be facilitated and given maximal support in the effort of increasing students' self-confident and their success later on.

Outcomes of the graduates of TVET in higher Education will give big contribution towards market demand even the society needs of business and industry. The relation between learning process in this case is the Production based learning model, TVET graduates outcomes in higher education and market demands can be seen in the fig. 1 . The figure shows the condition that related each other or link match. By the implementation in large number for this model is hoped to be able to give real contribution towards changes of national problem especially in the effort of decreasing number of educated unemployed. 


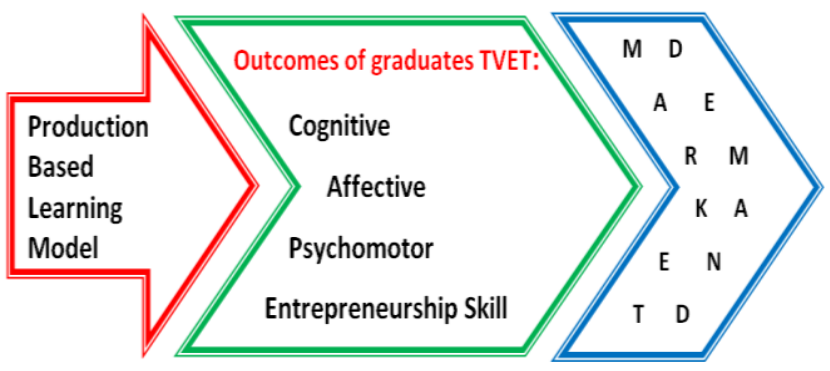

Fig. 1. Link and match between teaching and learning, outcomes of graduate and market demand

\section{Conclusion}

The production based learning model gives positive impact towards TVET graduates in the higher education. It is not only from the competency aspect which is good formed but also additional readiness which is given such as entrepreneurships skill to survive and compete in the free trading era. The production based learning model gives spaces for the students to be more brave, creative, and critical thinking regarding what they are doing. Besides, what the students have result have plus value scientifically and financially to be accepted in the society as a goods or services needed. This activity is better in the effort of building students' entrepreneurial interest. By this paper, it is time for the stakeholder TVET in higher education try to implement production based learning model in the learning process especially in practice learning. The implementation of this model is also be able to be implemented in the different field and materials review but it is still in line with field of TVET where in its implementation results product and doing handwork or hands on can be implemented.

\section{References}

[1] Bird. (1989). "Entrepreneurship; Organizational behavior; New business enterprises; Creative ability in business; Management". Scott, Foresman (Glenview, Ill.)

[2] Breen \& Bergin. (1999). "Small and Medium Enterprises in Asian Pacific Countries: Development Prospects". Nova Publishers. Copyright.

[3] Brennan, L. (2005). "Integrating work-based learning into higher education: A guide to good practice". A Report by the University Vocational Awards Council, University of Bolton, Bolton, MA.

[4] Brown, J., \& Duguid, P. (2001). "Knowledge and organisation: A social-practice perspective". Organization Science, 12(2), pp 198-213.

[5] Buang, Nor Aishah \& Ariffin, Siti Rahaya. (1995). "The relationship between technology and entrepreneurship education: its role in determining the competitiveness of commercial and industrial community". Bumiputera Abad 21. Seminar Kebangsaan Pendidikan Negara Abad ke-21, pp 282289.

[6] Burns, G., \& Chisholm, C. (2005). "Graduate to professional engineer in a knowledge organisation-does the undergraduate curriculum provide the basic skills?". Global Journal of Engineering Education, 9(1), pp 89-96.

[7] Chiva, R., \& Alegre, J. (2005). "Organizational learning and organizational knowledge". Management Learning, 36(1), pp 49-68.

[8] Derksen, J.T.P (2000). "De ondernemende onderzoeker'paradox of pleonasme. The Entrepreneurial Researcher: paradox or pleonasm?" .Oratie. Nijmegen: KUN

[9] Duch, B., Groh, S., \& Allen, D. (2001). "The power of problembased learning". Sterling, VA: Stylus
[10] Elfring, T. (1999). "Oplevend Entrepreneurschap. Oratie". Revival of Entrepreneurship, Wageningen: Wageningen University

[11] Frazier, Barbara and Niehm, Linda S. (2008). "FCS Students' Attitudes and Intentions Toward Entrepreneurial Careers". Journal of Family and Consumer Sciences; Apr 2008; 100,2; ProQuest Education Journals, pp. 17

[12] Ganefri and Hidayat, Hendra. (2014). "Production based Learning: An Instructional Design Model in the Context of Vocational Education and Training (VET)". Global Journal of Science Frontier Research (GJSFR) Volume 14 Issue 3. ISSN Online: 2249-4626, Print: 0975-5896

[13] Ganefri. (2013). "The Development of Production-Based Learning Approach to Entrepreneurial Spirit for Engineering Students". Journal Asian Social Science; Vol. 9, No. 12; pp 162167

[14] Ghazali, Radzuan. (2012). "Instrument to Measure Students' Entrepreneurial Ability Developed”. 12 January 2012 12:00 . online. http://www.ukm.my/news/index.php/research-news/951instrument-to-measure-students-entrepreneurial-abilitydeveloped.html.

[15] Gibb, A. (1995). "Entrepreneurship in the Transition Economies: Back to the Future". Economic Reform Today. Vol.4. pp 9

[16] Gibb, A. (1995). "Entrepreneurship in the Transition Economies: Back to the Future". Economic Reform Today. Vol.4. 1995. pp 9

[17] Higgins, D. (2008). "Developing practicing managers: Managerial learning as a practice in the SME firm". Paper presented at the 32nd ISBE Conference International Entrepreneurship Conference, Liverpool.

[18] Huggins, R., Jounes, M. \& Upton, S. (2008). "Universities as drivers of knowledge-based regional development: A triple helix analysis of Wales". International Journal of Innovation and Regional Development, 1(1), pp 24-27

[19] Igweh, A. U. (2005). "Entrepreneurship Education in Technology Programmes: A panacea for sustainable youth empowerment in Nigeria in proceedings of the 1st Annual National Conference of Nigerian Association of Teachers of Technology (NATT)". Lagos: Rothemed International Ltd

[20] Johannisson, B., Halvarsson, D. \& Lovstal, F. (1997). "Stimulating and Fostering Entrepreneurship through University Training - learning within an organizing context". Paper for IntEnt97.

[21] Kao, J. (1989). "Entrepreneurship, Creativity \& Organisation". Englewood Cliffs: Prentice Hall.

[22] Kent, C.A. (1990). "Entrepreneurship Education at the Collegiate Level: A Synopsis and Evaluation." In C.A. Kent (Ed.) Entrepreneurship Education, pp. 111-122. New York:Quorum Books

[23] Klandt, H. (1998). "Entrepreneurship Education at the European Business School”. Paper for IntEnt98.

[24] LOSBenRM (National Council for Small business and Retail Management Training). (1999). “Competentiegerichte hogere beroepsopleiding Small Business \& Retail Management. [Competence Directed Higher Education for Small Business and Retail Management]" Enschede: Landelijk Overleg Small Business \& Retail Management.

[25] Maclean, Rupert, \& Wilson, David. 2009. "International Handbook of Education for the Changing World of Work".Springer Science+Business Media B.V.

[26] Mohan-Neill, S. (1997). "The Perceived Needs, Benefits and Potential Target Markets for Entrepreneurship Education". Paper for IntEnt97 Conference. Hinsdale, Il: Roosevelt University

[27] Nwaokolo, P. O. E. (2005). "Modalities for Teaching Entrepreneurship in Technical Institutions. A paper presented at Capacity Building Workshop for Lecturers of Polytechnics and Monotechnics in Nigeria held at Akwa Ibom State Polytechnic", Ikot Osurua, 18th - 20th September, 2005

[28] Prawiradilaga, Dewi Salma. (2008). "Principles of Learning Design". Publisher : State University of Jakarta . Jakarta-Ind 
[29] Putra, Rano Aditia. (2012). "Determinants of Interest Management Students For Entrepreneurship". journal of Management, Volume 01, Nomor 01, September 2012

[30] Rabbior, Gary. (1990). "Entrepreneurship for Canadians: the spirit of adventure. Toronto : Canadian Foundation for Economic Education.

[31] Ronstadt. (1984). “Entrepreneurship”. Dover, MA, Lord Publishing

[32] Sanjaya, Winna. (2006). "Learning Strategies : Standard Process Oriented Education". Publisher : Kencana Prenada Media Group . Jakarta-Ind

[33] Sardiman. (2007). "Interaction and Learning Motivation" . Publisher : PT . King Grafindo Persada . Jakarta-Ind

[34] Schmitt, Eva and Rodermund. (2004). "Pathways to successful entrepreneurship: Parenting, personality, early entrepreneurial competence, and interests". Developmental Psychology, University of Jena, Am Steiger 3/1, D-07743 Jena, Germany, Journal of Vocational Behavior, pp 498-518

[35] Singh, Madhu. (2009). "School Enterprises Revisited: Combining Vocational Learning with Production". UNESCO Institute for Lifelong Learning, Hamburg, Germany J. Fien et al. (eds.), Work, Learning and Sustainable Development, Springer Science+Business Media B.V

[36] Sukmadinata, Syaodin. (2008). "Educational Research Methods". Bandung: PT . Teens Rosdakarya Offset - Ind

[37] Uslay, Can., Teach, Richard D. and Schwartz, Robert G. (2002). "Promoting Entrepreneurship for Economic Development: A Cross-Cultural Analysis of Student Attitudes". Journal of Research in Marketing \& Entrepreneurship: Volume 4, Issue 2, pp $101-118$

[38] Wang, Clement K and Wong, Poh-Kam. (2004). "Entrepreneurial interest of university students in Singapore", Centre for Entrepreneurship, National University of Singapore, Technovation Journal,pp 163-172

[39] Zaidatol Akmaliah Lope Pihie \& Habibah Elias. (1987). "Teaching Entrepreneurship and Commerce". Publisher Fajar Bakti Sdn . Bhd

[40] Zimmerer, W. Thomas M.. Scarborough. (1996). "Entrepereneurship and the new venture formation". New Jersey: Prentice Hall International Inc, pp 14-17. 